\title{
Financing Development in Latin America
}

Each volume in this series is designed to make available to students important new work on key historical problems and periods that they encounter in their courses. Every volume is devoted to a central topic or theme, and the most important aspects of this are dealt with by specially commissioned essays from specialists in the period. The editorial Introduction reviews the problem or period as a whole, and each essay provides a balanced assessment of the particular aspect, pointing out the areas of development and controversy and indicating where conclusions can be drawn or where further work is necessary. An annotated bibliography serves as an up-to-date guide to further reading. 


\section{PROBLEMS IN FOCUS SERIES}

Britain after the Glorious Revolution 1689-17I4

edited by Geoffrey Holmes

Britain Pre-eminent: Studies of British world

influence in the nineteenth century

edited by C. J. Bartlett

Popular Movements c. $1830-50$ edited by J. T. Ward

The Republic and the Civil War in Spain

edited by Raymond Carr

Financing Development in Latin America

edited by Keith Griffin

The Hundred Years War edited by Kenneth Fowler

FORTHCOMING TITLES

Great Politicians and Their Electoral Appeal 1860-1920

edited by Donald Southgate

Aspects of Victorian Liberalism edited by Leyland Lyons

The Interregnum edited by Gerald Aylmer

Urban Studies edited by A. M. Everett

Industrial Revolutions edited by R. M. Hartwell

Sweden $1632-1718$ edited by Michael Roberts

The Reign of fames VI and I edited by A. G. R. Smith

The Origins of the Civil War edited by Conrad Russell 


\title{
Financing
}

\section{Development in \\ Latin America}

\author{
EDITED BY \\ KEITH GRIFFIN
}

Macmillan Education 


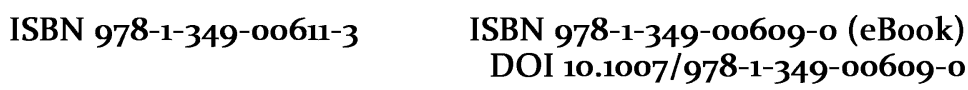

(C) Keith Griffin, Lester C. Thurow, forge Arrate, Lucio Geller, Laurence Whitehead, Arthur L. Domike, Victor E. Tokman, Timothy King, Rosemary Thorp 1971

Softcover reprint of the hardcover 1st edition 1971 978-0-333-09131-9

All rights reserved. No part of this publication may be reproduced or transmitted, in any form or by any means, without permission.

$$
\begin{array}{r}
\text { First published 1971 by } \\
\text { MACMILLAN AND CO L TD } \\
\text { London and Basingstoke }
\end{array}
$$
Associated companies in New York Toronto Dublin Melbourne fohannesburg and Madras

Library of Congress Catalog Card No. 70-145587

SBN 333 0913I ० (hard cover) 


\section{Contents}

$\begin{array}{ll}\text { Preface } & \text { ix }\end{array}$

Introduction: Monopoly Power, Material Progress and the Economic Surplus

KEITH GRIFFIN

(a) Origins of Monopoly

(b) Income Distribution and the Surplus 5

(c) The Role and Nature of Government 12

(d) Conclusion $\quad 18$

I Development Finance in Latin America: Basic Principles 26

LESTER D. THUROW

(a) Theory $\quad 26$

(b) The Scene $3 \mathrm{I}$

(c) Generating Tax Revenue 40

(d) Specific Taxes 43

(e) Utilisation of Resources $\quad 48$

(f) Conclusion $\quad 49$

2 Economic Surplus and the Budget $5 \mathrm{I}$

JORGE ARRATE and LUCIO GELLER

(a) Fiscal Policy, Effective Demand and Economic Surplus 52

(b) Public Appropriation of the Economic Surplus 55

(c) Public Use of the Economic Surplus 58

(d) Tax Policy in a Backward Country 63

(e) Redistribution and Economic Growth: The Limitations of Fiscal Policy

3 Public Sector Activities

LAURENCE WHITEHEAD

(a) Public Enterprise in the Development Process 73

(b) Latin America's Public Sector 79

(c) Social Security Funds: A Neglected Source of Forced Savings

(d) Latin America's Development Banks 104

(e) Summary and Conclusion 108 
4 The Role of Agricultural Taxation in Financing Agricultural Development in Latin America

ARTHUR L. DOMIKE and VICTOR E. TOKMAN

(a) Introduction

(b) Some Essential Definitions II4

(c) Priorities in Agricultural Development II6

(d) Resource Requirements for Agricultural Development 122

(e) Resource Mobilisation for Agricultural Development $\quad$ I28

(f) Techniques for Mobilising Resources I30

(g) Tax Systems and Agricultural Development Strategies I3I

(h) Agricultural Taxation in Poor Agrarian Countries 132

(i) Agricultural Taxation in Urbanising Countries $\quad$ I36

(j) Tax Policies in the Relatively Urbanised Countries $\quad$ I39

(k) Peru: A Case Study in Financing Agrarian Reform 142

5 Private Savings

152

TIMOTHY KING

(a) Introduction $\quad 152$

(b) Data Problems $\quad$ I54

(c) Studies of Aggregate National Savings I6I

(d) Private Savings $\quad 165$

(e) Personal Savings $\quad 167$

(f) Personal Savings and the Functional Distribution of Income

(g) Savings and the Incentive to Invest 176

$\begin{array}{ll}\text { (h) Conclusion } & 179\end{array}$

6 Inflation and the Financing of Economic Development 182 ROSEMARY THORP

(a) Introduction $\quad 182$

(b) The Dimensions of the Question of Inflation 183

(c) The Background: The Various Approaches to the Analysis of Inflation $\quad 183$

(d) The Relationships between Inflation and Development 194

$\begin{array}{ll}\text { (e) Conclusion } & 218\end{array}$

7 The Role of Foreign Capital 225

KEITH GRIFFIN

(a) The Macro-economics of Foreign Capital 226

(b) Capital Imports and Domestic Consumption 228 
(c) The Contribution of Aid 23I

(d) The Importance of Private Foreign Investment 236

(e) International Capital Movements in a Dynamic World 239

Notes on Contributors $\quad 245$

Select Bibliography $\quad 246$

Index $\quad 255$ 


\section{Preface}

THERE is a considerable body of literature on the general aspects of economic development and on the problems of resource allocation and planning for faster growth, but there is relatively little material available in convenient form for the student interested in the financial aspects of development policy. The intention in preparing this volume was to examine the various ways in which resources could be mobilised in order to accelerate growth and diminish inequality in Latin America. We have concentrated on the problem of development, and ignored other possible objectives of public policy, in the belief that the promotion of greater material well-being for the mass of the population is, or ought to be, the primary concern of all governments in the region.

This approach has forced us to be comprehensive and to consider methods of raising finance that often are neglected in studies which concentrate on taxation. In addition to conventional fiscal instruments, we have examined the role played by nationalised enterprises, the possibilities of financing growth via inflation, the connection between income distribution and private savings, and the contribution of foreign capital. Each author has been free to develop his argument as he wished and no attempt has been made to present all sides of each issue. We have tried instead to provoke discussion and stimulate further research.

Oxford

K. B. G.

May 1970 